\title{
Sezaryen Sonrası Benlik Saygısı ve Vücut Algısı
}

\section{Self-Esteem and Body Image After Cesarean Section}

\author{
Aylin Aydın Sayılan ${ }^{1 *}$, Ezgi Seyhan $\mathrm{Ak}^{2}$, Ezginur İnan ${ }^{1}$, Ayşe Kavasoğlu ${ }^{3}$ \\ ${ }^{1}$ Kırklareli Üniversitesi Sağlık Yüksekokulu Hemşirelik Bölümü, Kırklareli, Türkiye. \\ ${ }^{2}$ İstanbul Üniversitesi Florence Nightingale Hemşirelik Fakültesi Cerrahi Hastalıkları Hemşireliği Anabilim Dalı, \\ İstanbul, Türkiye. \\ ${ }^{3}$ Ümraniye Eğitim ve Araştırma Hastanesi Kadın Hastalıkları ve Doğum Anabilim Dalı, İstanbul, Türkiye.
}

e-mail: aylinay_85@msn.com, esqii_11@windowslive.com, ezginur.inan@hotmail.com,

kavasogluaysee@gmail.com

Orcid: 0000-0003-0576-8732

Orcid: 0000-0002-3679-539X

Orcid: 0000-0003-4887-6151

Orcid: 0000-0001-9765-1851

*Sorumlu Yazar / Corresponding Author: Sorumlu Yazar: Aylin Aydın Sayılan

Gönderim Tarihi / Received: 05.12.2018

Kabul Tarihi / Accepted: 29.12.2019

DOI: $10.344156087 /$ cbusbed.49

\section{Özet}

Amaç: Çalışmada, cerrahi bir girişim olan sezaryen sonrasında, benlik saygısı ve vücut algısı arasındaki ilişkinin belirlenmesi amaçlanmıştır.

Gereç ve Yöntem: Tanımlayıcı kesitsel ve analitik tipte olan çalışmada; araştırma evrenini, iki devlet hastanesinin Kadın Doğum Servis'lerinde sezaryen olup, polikliniğe kontrol amaciyla gelen anneler, örneklemini Haziran Ağustos 2017 tarihleri arasında polikliniğe kontrol amacıyla gelen 18-45 yaş arası, 145 anne oluşturmuş̧ur. Veri toplama aracı olarak, literatür doğrultusunda hazırlanan soru formu, Rosenberg Benlik Saygısı Ölçeği ve Vücut Algısı Ölçeği uygulandı. Veriler yüz yüze görüşme yöntemiyle toplanmıştır.

Bulgular: Çalışmaya katılan annelerin yaş ortalamalarının $28,94 \pm 5,16$; \%37,24'ünün lise mezunu, \%73,10'unun aylık gelirinin orta düzeyde olduğu; \%82,76'sının herhangi bir kronik hastalığının olmadığı belirlenmiştir. Çalışmada

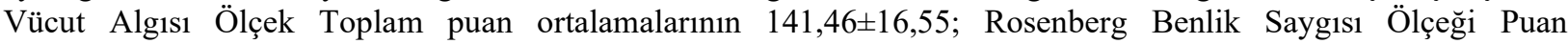

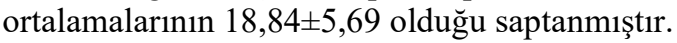

Sonuç: Sezaryen sonrası annelerin, benlik saygılarının yeterli; vücut algılarının orta düzeyde olduğu görülmüştür. Vücut algısı ölçeği puanları ile Rosenberg Benlik Saygısı Ölçeği puanları arasında negatif yönde anlamlı ilişki olduğu, vücut algısı ölçeği puanları arttıkça Rosenberg Benlik Saygısı Ölçeği puanlarının azaldığı saptanmıı̧tır.

Anahtar Kelimeler: Sezaryen, benlik saygisı, beden, alg1

\footnotetext{
Abstract

Objective: The aim of the study is to determine to relationship between self-esteem and body perception after cesarean.

Materials and Method: This is a descriptive, analytic and cross-sectional study. It included two maternity nursing departments of the two hospitals in June- August 2017 and the mothers who came for the control of the polyclinic were selected from 18-45 years old, 145 mothers who were able to in our study. Data collected by questionnaire form which occur literature and Rosenberg Self-Esteem Scale, and Body-Perception Scale. The data were collected by faceto-face interview method.

Results: The mean age of the participating mothers was $28,94 \pm 5,16 ; 37,24 \%$ high school graduates and $73,10 \%$ have middle income rate; $82.76 \%$ of them did not have any chronic disease. Body Perception Scale at Work Scale of total points is $141,46 \pm 16,55$; Rosenberg Self-Esteem Scale averages of $18,84 \pm 5,69$ were identified.
} 
Conclusion: In line with these conclusions, mothers' self-esteem is sufficient; and it was observed that body perception was moderate after cesarean. It was found that there was a negative correlation between the scores of body perception scale and Rosenberg Self-Esteem Scale scores and the scores of Rosenberg Self-Esteem Scale decreased as the scores of body perception scale increased.

Keywords: Cesarean, self-esteem, body image.

\section{Giriș}

Kadın ve ailesi için doğum deneyimi hayatın birçok sürecini etkileyen önemli bir faktördür [1]. Gebelik ve doğum, fizyolojik bir süreç olmasına karşın, kadın vücudu için önemli bir yük ve stres oluşturmaktadır. Doğum sonrası dönem fizyolojik olduğu kadar kalıcı psikolojik değişikliklere de neden olmaktadır [2]. Benlik saygısı, bireyin kendini beğenme, kendi yaşam biçimini algılama ve geçirdiği yaşantıları sonucunda kendisine yüklediği değerler olarak tanımlanmakta; benlik kavramının beğenilip beğenilmemesini kapsamaktadır [3]. Vücut alg1s1 ise, bedenimizin zihnimizde biçimlendirdiğimiz şeklidir. Bireyin kendi bedeni ile ilgili zihninde oluşturduğu görüntü, bedenin özellikleri ve işlevselliği, bedenini algılama şekli beden imajının temel bileşenlerini oluşturmaktadır. Bedenin zihindeki görüntüsüyle, bireyin algıladığı bedeni arasında bir uyuşmazlık olduğunda, vücut algısı bozulmaktadır. Gebelik, kadın yaşamının önemli dönemlerinden biri olmakla birlikte, gebelik ve doğum sonrası dönemde yeni ve farklı durumlara uyum sağlamaya çalışan kadının aynı zamanda vücut algisı da etkilenebilmektedir [4]. Literatürde, sezaryen doğum sonrası vücut algılarının bozulduğu, bu nedenle benlik saygılarının düştüğü, sonucunda kontrol kaybı ve hayal kırıklığı yaşadıkları bildirilmektedir [5].

Gebelik sırası ve doğum sonrasındaki vücut algısı, kadın vücudunda meydana gelen hızlı fiziksel değişikliklere bağlı olarak değişmekte; bu değişimler benlik saygısı üzerinde olumlu veya olumsuz etkilere neden olmaktadır $[5,6,7,8]$. Sezaryen sonrası deneyimlenen düşük benlik saygısı, destek sistemlerinin olmayışı, evlilik problemleri, devam eden yorgunluğu, doğumdan sonra kendi ve bebeği için bakım yetersizliklerine de neden olabilmektedir. Literatürde, benlik saygısı yüksek annelerin, koşullu veya şartsız kendini kabul etme, stresli veya olumsuz olayların nasıl yaşanacağını öngörme yeteneklerinin de daha yüksek olduğu vurgulanmaktadır $[10,11]$. Doğum sonu dönemdeki sağlık bakımında; annelerin fizyolojik, psikolojik ve sosyal gereksinimlerinin karșılanması; yaşanan değișimlerin farkında olunması, fiziksel ve ruhsal sağlıkları üzerinde olumlu etki yarattığı, bu nedenle sağlı bakım profesyonellerine önemli sorumluluklar düştüğü belirtilmektedir [6].

Bu bilgiler 1şığında, annelerin doğum sonrası dönemdeki bakım gereksinimlerinin değerlendirilmesi, bu konuda gerekli bakım ve desteğin sağlanması ile annelik rolüne uyumları kolaylaştırılmalı ve annelerin yaşadıkları sorunlar sürekli olarak değerlendirilmelidir. Bunun yanında sağlık profesyonelleri annelerin doğum ve doğum sonrası döneme yönelik yanlış inanışlarının farkında olmalı ve şartsız olarak kendini kabullenme durumlarını arttırmak için doğum sırasında ve sonrasında kadınları olumlu bir şekilde güçlendirmelidir.

\section{Materyal ve Metod}

Araştırmanın Türü: Araştırma, sezaryen sonrası benlik saygısı ve vücut algısı arasındaki ilişkinin belirlenmesi amacıyla tanımlayıcı kesitsel ve analitik olarak gerçekleştirildi.

Araştırmanın Yeri ve Zamanı: Araştırma HaziranAğustos 2017 tarihleri arasında iki devlet hastanesinin Kadın Doğum Servis'lerinde yürütüldü.

Araştırmanın Evren ve Örneklemi: Araştırma evrenini, Kırklareli'de bulunan iki hastanenin Kadın Doğum Servis'lerinde sezaryen olan anneler, örneklemini ise Haziran - Ağustos 2017 tarihleri arasında polikliniğe kontrol amaciyla gelen 18-45 yaş arası, okuryazar olan, mental sağlığ 1 yerinde olan ve iletişim kurabilen, doğum sonrası herhangi bir komplikasyon gelişimi olmayan 145 anne oluşturdu. İlgili tarihlerde polikliniğe 324 hasta gelmiş olup, çalışmaya katılım oranı $\% 44,75$ olarak belirlenmiştir.

\section{Veri Toplama Araçları}

Veriler; araştırmacılar tarafından literatür doğrultusunda geliştirilen, "Bilgi Formu", Rosenberg Benlik Saygısı Ölçeği ve Vücut Algısı Ölçeği kullanılarak toplandı $[12,13]$.

Bilgi Formu: Formda sezaryen olan annelerin tanımlayıcı özelliklerine ilişkin yaş, boy, kilo, eğitim durumu, medeni durum, mesleği, aylık kazanç durumu, sağlık güvencesi, sigara ve alkol kullanma durumu, kronik hastalık varlığı, çocuk sayısı, toplam doğum sayısı ve son gebelikte aldığ yer aldı.

Rosenberg Benlik Saygısı Ölçeği (Rosenberg Self-esteem Scale): Rosenberg Benlik Saygısı Ölçeği, çoktan seçmeli 63 sorudan oluşan bir özbildirim ölçeğidir. Ölçek, on iki alt kategoriden oluşmaktadır. Araştırmanın amacı doğrultusunda benlik saygısını ölçmeye yönelik olarak, ölçeğin ilk "on" maddesi kullanılmaktadır. Ölçekte; 1, 2, 4, 6, 7. maddeler olumlu kendilik değerlendirmesini sorgulamakta olup, 3'den 0'a kadar değişen puanlama yapılırken, 3, 5, 8, 9, 10. maddeler olumsuz kendilik değerlendirmesini sorgulamakta olup, 0'dan 3'e kadar değişen bir puanlama yapılmaktadır. Toplam puan aralığ 1 0-30 arasında olup, 15-25 arası alınan puan benlik saygısının yeterli olduğunu gösterirken, 15 puanın altı düşük benlik saygısını göstermektedir [12,13,14]. Ülkemizde ölçeğin geçerlilik ve güvenilirlik çalışmaları Çuhadaroğlu tarafından yapılmış olup, iç tutarlılık güvenirlik kat sayısı $\alpha=0.71$ olarak bulunmuştur. Test- 
tekrar test güvenilirlik yöntemi kullanılarak da güvenilirlik kat sayısı $r=0,75$ olarak saptanmıştır [15].

Vücut Algısı Ölçeği (VAÖ): Vücut Algısı Ölçeği (VAÖ) 1953 yılında Secord ve Jourand tarafından geliştirilmiş, 1989 yılında Hovardaoğlu tarafından geçerlilik ve güvenilirliği yapılmıştır. Ölçeğin iki yarım güvenirliği 0,89 olarak bulunmuştur $(\mathrm{p}<.05)$. Bu bulgu ölçeğin güvenirliğinin yüksek olduğunu göstermektedir. Cronbach's Alpha değerlerine bakıldığında ölçeğin iki yarısına ait iç tutarlık katsayılarının, sırasıyla 0,79 ve 0,87 olduğu bulunmuştur. Ölçeğin tümünün iç tutarlık katsayısı 0,95'tir. Ölçek 40 madde içermekte olup, her bir madde bir organ ya da bedeninin bir bölümü (kol, bacak yüz gibi) ya da bir işlevi (cinsel faaliyet düzeyi) ile ilgilidir. Her bir madde için 1' den 5'e kadar değişen puanlar alan ve "hiç beğenmiyorum", "beğenmiyorum", "kararsızım", "beğeniyorum" ve "çok beğeniyorum" şeklinde yanıt seçeneği bulunan ölçeğin toplam puanı 40 ile 200 arasında değişmekte olup, alınan toplam puanın yüksek olması doyum düzeyinin yüksekliğini göstermektedir. Ölçeğin kesme puanı 135 olup, 135 altında puan alanlar beden algısı düşük grup olarak tanımlanmıştır [13,16,17,18].
Araştırma Sorulart: Annelerin benlik saygı düzeyleri ile vücut algı düzeyleri arasında anlamlı bir ilişki var mıdır? Etik Yaklaşım: Çalışmaya başlamadan önce, Kırklareli Üniversitesi Sağlık Bilimleri Enstitüsü Etik Kurulu'ndan izin alındı. (No: P037R00). Çalışmada insan olgusunun kullanımı, bireysel hakların korunmasını gerektirdiğinden, "bilgilendirilmiş izin" koşulu bir etik ilke olarak yerine getirilerek ve örneklem kriterlerini karşılayan annelerden yazılı ve sözlü izin alındı.

Verilerin Değerlendirilmesi: $\mathrm{Bu}$ çalışmada elde edilen veriler IBM SPSS Statistics Version 22 paket programı ile analiz edildi. Annelerin tanıtıcı özellikleri; sayı, yüzde, ortalama, standart sapma olarak verildi. Ölçek puanları arasındaki ilişki korelasyon ile belirlendi. Anlamlılık $\mathrm{p}<0,05$ düzeyinde değerlendirildi.

\section{Bulgular}

Çalışmaya katılan annelerin yaş ortalamalarının 28,94 $\pm 5,16$; tamamının evli; \%15,17'sinin memur olduğu; olduğu \%37,24'ünün lise mezunu, \%73,10'unun aylık gelirinin orta düzeyde; \%84,83'ünün sağlık güvencesinin

Tablo 1. Tanıtıcı Özelliklere İlişkin Frekans Dağılım

\begin{tabular}{|c|c|c|c|}
\hline & & (Ortalama \pm Standart sapma) \\
\hline \multicolumn{2}{|l|}{ Yaş } & & $28,94 \pm 5,16$ \\
\hline \multicolumn{2}{|l|}{ Boy $(\mathrm{cm})$} & & $160,93 \pm 6,46$ \\
\hline \multicolumn{2}{|l|}{ Kilo (kg) } & & $71,01 \pm 11,23$ \\
\hline & & $\mathbf{n}$ & $\%$ \\
\hline \multirow{2}{*}{ Medeni Durum } & Bekar & 0 & 0,00 \\
\hline & Evli & 145 & 100,00 \\
\hline \multirow[t]{4}{*}{ Meslek } & Memur & 22 & 15,17 \\
\hline & Serbest meslek & 18 & 12,41 \\
\hline & İşçi & 29 & 20,00 \\
\hline & Diğer (ev hanımı) & 76 & 52,41 \\
\hline \multirow[t]{4}{*}{ Eğitim Durumu } & İlkokul & 40 & 27,59 \\
\hline & Ortaokul & 32 & 22,07 \\
\hline & Lise & 54 & 37,24 \\
\hline & Üniversite & 19 & 13,10 \\
\hline \multirow[t]{3}{*}{ Aylık Kazanç Durumu } & Düşük & 17 & 11,72 \\
\hline & Orta & 106 & 73,10 \\
\hline & Yüksek & 22 & 15,17 \\
\hline \multirow[t]{2}{*}{ Sağlık Güvencesi } & Emekli sandığı & 22 & 15,17 \\
\hline & SGK & 123 & 84,83 \\
\hline \multirow[t]{2}{*}{ Sigara İçme Durumu } & İçiyor & 13 & 8,97 \\
\hline & İçmiyor & 132 & 91,03 \\
\hline \multirow[t]{2}{*}{ Alkol Alma Durumu } & Kullanıyor & 3 & 2,07 \\
\hline & Kullanmiyor & 142 & 97,93 \\
\hline \multirow[t]{3}{*}{ Kronik Hastalıklar } & Yok & 120 & 82,76 \\
\hline & Var & 25 & 17,25 \\
\hline & Toplam & 145 & 100,00 \\
\hline
\end{tabular}


SGK olduğu; \%91,03'ünün sigara içmediği, \%97,93'ünün alkol kullanmadığ $1, \% 82,76$ 'sının herhangi bir kronik hastalığının olmadığı belirlendi (Tablo 1).

Çalışmaya katılan annelerin çocuk sayısı ortalamalarının $1,43 \pm, 93$; toplam gebelik sayısı ortalamalarının $2,22 \pm 1,05$ olduğu, son gebelikte kazanılan kilo ortalamalarının ise 14,98 $\pm 6,09$ olduğu saptandı (Tablo 2).

Tablo 2. Obstetrik Özelliklere İlişkin Dağılımlar

\begin{tabular}{|l|c|c|c|c|c|}
\hline & $\mathrm{n}$ & Mean & Median & Min & Max \\
\hline Çocuk Sayıs1 & 145 & 1,43 & 1,00 & 0 & 4 \\
\hline $\begin{array}{l}\text { Toplam Gebelik } \\
\text { Sayıs1 }\end{array}$ & 145 & 2,22 & 2,00 & 1 & 9 \\
\hline $\begin{array}{l}\text { Son Gebelikteki } \\
\text { Kazanılan Kilo (kg) }\end{array}$ & 145 & 14,98 & 14,00 & 0 & 29 \\
\hline
\end{tabular}

Çalışmada Vücut Algısı Ölçek Toplam puan ortalamalarının 141,46 $\pm 16,55$; Rosenberg Benlik Sayg1S1 Ölçeği Puan ortalamalarının 18,84 $\pm 5,69$ olduğu belirlendi (Tablo 3). Çalışmaya katılan annelerin \%69,66'sının vücut algısı düzeyinin yüksek; \%90,34'ünün ise benlik saygısının yüksek düzeyde olduğu görülmüştür (Tablo 3).

Tablo 3. Vücut Algısı Ölçeği ve Rosenberg Benlik Saygısı Ölçeği Puanlarına İlişkin Dağılım

\begin{tabular}{|l|c|c|c|c|}
\hline & $\mathrm{n}$ & Mean & $\begin{array}{c}\text { Medi } \\
\text { an }\end{array}$ & ss \\
\hline Vücut Algısı Ölçeği Puanı & 145 & 141,46 & 140 & 16,5 \\
\hline $\begin{array}{l}\text { Rosenberg Benlik Saygısı Ölçeği } \\
\text { Puanı }\end{array}$ & 145 & 18,84 & 18,2 & 5,6 \\
\hline
\end{tabular}

\begin{tabular}{|l|l|c|l|}
\hline \multicolumn{2}{|c|}{} & $\mathrm{n}$ & \multicolumn{1}{c|}{$\%$} \\
\hline Vücut Alg1s1 Düzeyi & Düşük & 44 & 30,34 \\
\cline { 2 - 4 } & Yüksek & 101 & 69,66 \\
\cline { 2 - 4 } & Toplam & 145 & 100 \\
\hline \multirow{3}{*}{ Benlik Sayg1S1 } & Orta & 14 & 9,66 \\
\cline { 2 - 4 } & Yüksek & 131 & 90,34 \\
\cline { 2 - 4 } & Toplam & 145 & 100 \\
\hline
\end{tabular}

n:kişi sayısı

Vücut algısı ölçeği puanları ile kendilik kavramının sürekliliği puanları arasında negatif yönde anlamlı ilişki olduğu, vücut algısı ölçeği puanları arttıkça kendilik kavramının sürekliliği puanları azaldığı $(\mathrm{r}=-0,288)$; vücut algısı ölçeği puanları ile tartışmalara katılabilme derecesi puanları negatif yönde anlamlı ilişki olduğu, vücut algısı ölçeği puanları arttıkça tartışmalara katılabilme derecesi puanlarının azaldığı $(\mathrm{r}=-0,228)$; vücut algısı ölçeği puanları ile ana-baba ilgisi puanları arasında negatif yönde anlamlı ilişki olduğu, vücut algısı ölçeği puanları arttıkça ana-baba ilgisi puanlarının azaldığı $(r=-0,301)$; vücut algısı ölçeği puanları ile psişik izolasyon puanları arasında negatif yönde anlamlı ilişki olduğu, vücut algısı ölçeği puanları arttıkça psişik izolasyon puanlarının azaldığ $1(\mathrm{r}=-0,307)$ belirlendi.
Vücut algısı ölçeği puanları ile Rosenberg Benlik Saygısı Ölçeği puanları arasında negatif yönde anlamlı ilişki olduğu, vücut algısı ölçeği puanları arttıkça Rosenberg Benlik Saygısı Ölçeği puanlarının azaldığı görüldü ( $\mathrm{r}=-$ 0,315) (Tablo 4).

Tablo 4. Ölçek Puanları Arasındaki İlişkiye Dair Korelasyon Testi Sonucu

\begin{tabular}{|c|c|c|}
\hline & & $\begin{array}{l}\text { Vücut Alg1s1 } \\
\text { Ölçeği Puan1 }\end{array}$ \\
\hline \multirow[t]{3}{*}{ Benlik Saygısı } & $\mathrm{r}$ &, 056 \\
\hline & $\mathrm{p}$ &, 500 \\
\hline & $\mathrm{n}$ & 145 \\
\hline \multirow{3}{*}{$\begin{array}{l}\text { Kendilik Kavramının } \\
\text { Sürekliliği }\end{array}$} & $\mathrm{r}$ &,$- 288^{* *}$ \\
\hline & $\mathrm{p}$ &, 001 \\
\hline & $\mathrm{n}$ & 145 \\
\hline \multirow[t]{3}{*}{ İnsanlara Güven Duyma } & $\mathrm{r}$ &,- 143 \\
\hline & $\mathrm{p}$ & ,086 \\
\hline & $\mathrm{n}$ & 145 \\
\hline \multirow[t]{3}{*}{ Eleştiriye Duyarlılık } & $\mathrm{r}$ &,- 059 \\
\hline & $\mathrm{p}$ & ,482 \\
\hline & $\mathrm{n}$ & 145 \\
\hline \multirow[t]{3}{*}{ Depresif Duygulanım } & $\mathrm{r}$ &,- 029 \\
\hline & $\mathrm{p}$ & ,733 \\
\hline & $\mathrm{n}$ & 145 \\
\hline \multirow[t]{3}{*}{ Hayalperestlik } & $\mathrm{r}$ & ,006 \\
\hline & $\mathrm{p}$ & ,947 \\
\hline & $\mathrm{n}$ & 145 \\
\hline \multirow[t]{3}{*}{ Psikosomatik Belirtiler } & $\mathrm{r}$ &,- 120 \\
\hline & $\mathrm{p}$ &, 150 \\
\hline & $\mathrm{n}$ & 145 \\
\hline \multirow{3}{*}{$\begin{array}{l}\text { Kişilerarası İlişkilerde Tehdit } \\
\text { Hissetme }\end{array}$} & $\mathrm{r}$ & ,014 \\
\hline & $\mathrm{p}$ &, 865 \\
\hline & $\mathrm{n}$ & 145 \\
\hline \multirow{3}{*}{$\begin{array}{l}\text { Tartışmalara Katılabilme } \\
\text { Derecesi }\end{array}$} & $\mathrm{r}$ &,$- 228^{* *}$ \\
\hline & $\mathrm{p}$ &, 006 \\
\hline & $\mathrm{n}$ & 145 \\
\hline \multirow{3}{*}{ Ana-Baba İlgisi } & $\mathrm{r}$ &,$- 301^{* * *}$ \\
\hline & $\mathrm{p}$ & ,001 \\
\hline & $\mathrm{n}$ & 145 \\
\hline \multirow[t]{3}{*}{ Babayla İlişki } & $\mathrm{r}$ &,- 083 \\
\hline & $\mathrm{p}$ & ,320 \\
\hline & $\mathrm{n}$ & 145 \\
\hline \multirow[t]{3}{*}{ Psişik İzolasyon } & $\mathrm{r}$ &,$- 307^{* *}$ \\
\hline & $\mathrm{p}$ & ,001 \\
\hline & $\mathrm{n}$ & 145 \\
\hline \multirow{3}{*}{$\begin{array}{l}\text { Rosenberg Benlik Saygısı } \\
\text { Ölçeği Toplam Puanı }\end{array}$} & $\mathrm{r}$ &,$- 315^{* *}$ \\
\hline & $\mathrm{p}$ & ,001 \\
\hline & $\mathrm{n}$ & 145 \\
\hline
\end{tabular}

Yapılan korelasyon analizinde, insanlara güven duyma puanları ile aylık kazanç durumları arasında istatistiksel olarak anlamlı farklılık olduğu $(\mathrm{p}<0,05)$, aylık kazancı orta düzeyde olanların insanlara güven duyma puanının aylık kazancı yüksek olanlara göre anlamlı derecede düşük olduğu belirlendi. Eleştiriye duyarlılık puanları bakımından aylık kazanç durumları arasında istatistiksel 
olarak anlamlı farklılık olduğu $(\mathrm{p}<0,05)$, aylık kazancı yüksek olanların eleştiriye duyarlılık puanının aylık kazancı düşük olanlara göre anlamlı derecede düşük olduğu saptandı. Tartışmalara katılabilme derecesi puanları bakımından aylık kazanç durumları arasında istatistiksel olarak anlamlı farklılık olduğu $(\mathrm{p}<0,05)$, aylık kazancı düşük ve orta düzeyde olanların tartışmalara katılabilme derecesi puanının aylık kazancı yüksek olanlara göre anlamlı derecede düşük olduğu görüldü. Aylık kazanç grupları arasında Vücut algısı

uanları açısından anlamlı bir farklılık görülmemektedir. ( $\mathrm{p}>0,05)$. İstatistiksel olarak anlamlı olmamakla birlikte gelir arttıkça vücut algısı puanı azalmaktadır (Tablo 5).

\section{Tartışma:}

Literatürde vücut algısı ve benlik sayg1sını inceleyen çalışmalar mevcutken sezaryen sonrası vücut algısı ve benlik saygısını inceleyen çalışmaya rastlanmamıştır [17].

Tablo 5. Rosenberg Benlik Saygısı Ölçeği Puanları ile Aylık Kazanç Durumu Arasındaki Farklılığa İlişkin Kruskal Wallis H Testi Sonucu

\begin{tabular}{|c|c|c|c|c|c|c|c|c|c|c|}
\hline \multirow{3}{*}{$\begin{array}{l}\text { Benlik Saygısı } \\
\end{array}$} & \multirow{3}{*}{ Düşük } & \multicolumn{6}{|c|}{ Aylık Kazanç Durumu } & \multicolumn{3}{|c|}{ Kruskal Wallis H Testi } \\
\hline & & \multirow{2}{*}{$\begin{array}{c}\mathbf{n} \\
17\end{array}$} & \multirow{2}{*}{$\begin{array}{l}\text { Ort. } \\
0,81\end{array}$} & \multirow{2}{*}{$\begin{array}{c}\text { Ortanca } \\
0,75\end{array}$} & \multirow{2}{*}{$\begin{array}{c}\text { Min } \\
0\end{array}$} & \multirow{2}{*}{\begin{tabular}{|l|} 
Max \\
2,83
\end{tabular}} & \multirow{2}{*}{$\begin{array}{c}\mathbf{S S} \\
0,62\end{array}$} & \multirow{2}{*}{$\begin{array}{c}\begin{array}{c}\text { Sira } \\
\text { Ort. }\end{array} \\
81,94\end{array}$} & \multirow{2}{*}{$\begin{array}{c}\mathbf{H} \\
1,841\end{array}$} & \multirow{2}{*}{$\begin{array}{c}\mathbf{p} \\
0,398\end{array}$} \\
\hline & & & & & & & & & & \\
\hline & Orta & 106 & 0,82 & 0,5 & 0 & 3,25 & 0,72 & 73,43 & & \\
\hline & Yüksek & 22 & 0,77 & 0,5 & 0,25 & 2,58 & 0,79 & 64,02 & & \\
\hline & Toplam & 145 & 0,81 & 0,5 & 0 & 3,25 & 0,72 & & & \\
\hline \multirow{4}{*}{$\begin{array}{l}\text { Kendilik } \\
\text { Kavramının } \\
\text { Sürekliliği }\end{array}$} & Düşük & 17 & 3,59 & 4 & 1 & 5 & 1,12 & 81,91 & \multirow[t]{3}{*}{2,19} & \multirow[t]{3}{*}{0,334} \\
\hline & Orta & 106 & 3,37 & 4 & 0 & 5 & 1,12 & 73,42 & & \\
\hline & Yüksek & 22 & 2,95 & 4 & 0 & 4 & 1,4 & 64,09 & & \\
\hline & Toplam & 145 & 3,33 & 4 & 0 & 5 & 1,17 & & & \\
\hline \multirow{4}{*}{$\begin{array}{l}\text { İnsanlara Güven } \\
\text { Duyma }\end{array}$} & Düşük & 17 & 1,71 & 2 & 1 & 3 & 0,69 & 68,12 & \multirow[t]{3}{*}{10,147} & \multirow[t]{3}{*}{0,006} \\
\hline & Orta & 106 & 1,73 & 2 & 0 & 5 & 0,92 & 68,7 & & \\
\hline & Yüksek & 22 & 2,32 & 2 & 1 & 4 & 0,72 & 97,48 & & \\
\hline & Toplam & 145 & 1,81 & 2 & 0 & 5 & 0,89 & \multicolumn{3}{|c|}{$2-3$} \\
\hline \multirow{4}{*}{$\begin{array}{l}\text { Eleştiriye } \\
\text { Duyarlılık }\end{array}$} & Düşük & 17 & 2,53 & 3 & 1 & 3 & 0,72 & 95,38 & \multirow[t]{3}{*}{6,91} & \multirow[t]{3}{*}{$\mathbf{0 , 0 3 2}$} \\
\hline & Orta & 106 & 1,73 & 2 & 0 & 3 & 1,27 & 71,36 & & \\
\hline & Yüksek & 22 & 1,36 & 0 & 0 & 3 & 1,53 & 63,59 & & \\
\hline & Toplam & 145 & 1,77 & 2 & 0 & 3 & 1,29 & & $3-1$ & \\
\hline Depresif & Düşük & 17 & 1,59 & 1 & 0 & 5 & 1,42 & 77,65 & 1,113 & 0,573 \\
\hline Duygulanım & Orta & 106 & 1,46 & 1 & 0 & 5 & 1,33 & 73,87 & & \\
\hline & Yüksek & 22 & 1,27 & 1 & 0 & 5 & 1,42 & 65,23 & & \\
\hline & Toplam & 145 & 1,45 & 1 & 0 & 5 & 1,35 & & & \\
\hline Hayalperestlik & Düşük & 17 & 0,76 & 0 & 0 & 3 & 1,09 & 76,15 & 1,262 & 0,532 \\
\hline & Orta & 106 & 0,69 & 0 & 0 & 4 & 1,05 & 74,14 & & \\
\hline & Yüksek & 22 & 0,55 & 0 & 0 & 4 & 1,18 & 65,09 & & \\
\hline & Toplam & 145 & 0,68 & 0 & 0 & 4 & 1,07 & & & \\
\hline Psikosomatik & Düşük & 17 & 2,12 & 2 & 0 & 6 & 1,76 & 60,88 & 3,38 & 0,185 \\
\hline Belirtiler & Orta & 106 & 2,97 & 2 & 0 & 10 & 2,28 & 76,81 & & \\
\hline & Yüksek & 22 & 2,23 & 2 & 0 & 6 & 1,63 & 64,02 & & \\
\hline & Toplam & 145 & 2,76 & 2 & 0 & 10 & 2,16 & & & \\
\hline Kişilerarası & Düşük & 17 & 1,47 & 1 & 0 & 3 & 1,01 & 80,29 & 0,69 & 0,708 \\
\hline İlişkilerde Tehdit & Orta & 106 & 1,25 & 1 & 0 & 3 & 0,86 & 71,72 & & \\
\hline Hissetme & Yüksek & 22 & 1,27 & 1 & 0 & 2 & 0,7 & 73,52 & & \\
\hline & Toplam & 145 & 1,28 & 1 & 0 & 3 & 0,86 & & & \\
\hline Tartışmalara & Düşük & 17 & 0,82 & 0 & 0 & 2 & 0,95 & 60,5 & 13,916 & 0,001 \\
\hline Katılabilme & Orta & 106 & 1,03 & 1 & 0 & 2 & 0,86 & 69,19 & & \\
\hline Derecesi & Yüksek & 22 & 1,73 & 2 & 1 & 2 & 0,46 & 101 & & \\
\hline & Toplam & 145 & 1,11 & 1 & 0 & 2 & 0,86 & & $1-32-3$ & \\
\hline Vücut AlgıSI & Düşük & 17 & 149,59 & 144 & 135 & 177 & 14,71 & 94,5 & 5,796 & 0,055 \\
\hline Ölçeği Puanı & Orta & 106 & 140,91 & 140,5 & 83 & 196 & 17,81 & 71,6 & & \\
\hline & Yüksek & 22 & 137,86 & 138 & 126 & 153 & 7,57 & 63,11 & & \\
\hline & Toplam & 145 & 141,46 & 140 & 83 & 196 & 16,55 & & & \\
\hline
\end{tabular}

min: minimum, max: maximum, n: kişi sayısı, Ort.: Ortalama, Sıra Ort.: Sıra ortalaması ss: Standart sapma 
$\mathrm{Bu}$ çalışma sezaryen sonrası benlik saygısı ve vücut algısının belirlenmesi amacıyla gerçekleştirildi.

Gebelik süreci kadınların hayatını önemli derecede etkileyen unsurdur. Kadınlar bu süreçte bedensel ve ruhsal olarak çok fazla değişime uğramaktadırlar [5]. Çırak ve Özdemir' in (2015) adölesan gebelerle yaptıkları çalışmada araştırma kapsamına alınan adölesan gebelerin vücut algısı ölçeği puanlarının 146士 23,9 olduğu; Kumcağız'ın (2012) çalışmasına göre, vücut algısının $139.8 \pm 25.2$ olduğu bildirilmektedir [3,4]. Taşpınar'ın (2015) gebelerle yaptığ toplam puan ortalamalarının 137,31 $\pm 33,46$ olduğu bulunmuştur. Bu çalışmada vücut algısı ölçek toplam puan ortalamalarının $141,46 \pm 16,55$ olduğu ve çalışmaya katılan annelerin \%69,66'sının vücut algı düzeylerinin yüksek olduğu görüldü. Bu çalışma sonucu Çırak ve Özdemir, Kumcağız ve Taşpınar'ın sonucu ile benzerlik göstermektedir. Sezaryen sonrası vücut algısı ile benlik saygısı arasındaki ilişkinin incelendiği bu çalışmada vücut algısı ile benlik saygısı arasında anlamlı ilişki olduğu belirlenmiştir. Sonucun bu yönde ortaya çıkması, vücut algısı ile benlik saygısı arasında ilișki olduğunu savunan çalışmaların sonuçlarını destekler niteliktedir $[19,20]$. Literatürde vücut alg1s1 ile benlik sayg1sı arasında doğrudan bir ilişkinin var olduğu bildirilmektedir [19,20,21]. O'Reilly ve ark. 2014'nın çalışmasında planlı sezaryen olan annelerin benlik saygılarının düşük olduğu belirlenmiştir [22]. Farrow ve Blissett (2007) başkalarına bağımlılık, bilgi eksikliği ve güçsüzlük duygularının düşük benlik saygısı ile ilişkili olduğunu göstermiştir [11]. Taşpınar'ın (2015) çalışmasında ise gebelerin benlik saygılarının yüksek olduğu görülmüştür.

Bu çalışmada da sezaryen sonrası annelerin Rosenberg Benlik Saygısı Ölçeği toplam puan ortalamalarının bulunmuştur. Taşpınar'ın çalışma sonuçlarıyla benzerlik gösteren bu sonuç doğrultusunda annelerin benlik saygılarının iyi olması bebeklerini daha iyi kabul etmelerini ve doğum sonrası dönemde daha az sorun

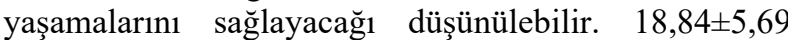
olduğu ve çalışmaya katılan annelerin \%90,34'ünün benlik saygılarının yüksek olduğu

Literatürde aylık gelirin vücut imajını etkilediği, aylık geliri yüksek olan gebelerin vücut imajının daha olumlu olduğu gösterilmektedir [3,4,23]. Taşpınar'ın (2015) çalışmasında gelir durumu yüksek olan kadınlarının vücut algılarının düşük, benlik saygılarının ise yüksek olduğu bulunmuştur. Field ve ark. (2018) yaptığı çalışmada, düşük gelirli gebe kadınların olumsuz beden algısına sahip olduklarını ifade ettikleri belirtilmektedir [24]. Bu çalışmada katılımcıların çoğunluğunun aylık kazancının orta düzeyde olduğu ve aylık kazanç ile vücut algısı ölçeği toplam puanları arasında anlamlı fark olmadığı saptandı $(\mathrm{p}>0,05)$. Ancak istatiksel açıdan anlamlı olmamakla birlikte gelir arttıkça vücut algısı puanlarının azaldığı görüldü. Çalışma bulguları Taşpınar'ın çalışma bulgularını destekler niteliktedir.
Yapılan bir çalışmada, gebe kadınların gebelik sayısı ile vücut algıları arasında negatif bir ilişki olduğu, gebelik sayısı az olan gebelerin vücut algılarının diğerlerine göre daha yüksek olduğu saptanmıştır [3]. Çırak ve Özdemir (2015) adölesan gebelerin gebelik sayısı, ilk gebelik yaşı, daha önce gebelik yaşayanlarda bir önceki gebelikle bu gebelik arasında geçen süreye göre vücut algısı puanlarıyla aralarında istatiksel açıdan önemli bir farkın olmadığ 1 belirlenmiştir [4]. Taşpınar'ın (2015) yaptığ çalışmada gebelik sayısı ile vücut algısı arasında anlamlı ilişki olmadığı bulunmuştur. Çırak ve Özdemir'in çalışma sonuçlarıyla benzerlik gösteren bu çalışmada da çocuk sayısı ile vücut algısı arasında anlamlı ilişki olmadığı; ancak çocuk sayısı ile benlik saygısı arasında anlamlı bir ilișki olduğu $(\mathrm{p}<0,05)$, çocuk sayısı arttıkça benlik saygısının da arttığı görüldü. Bu sonuç kültürel yapımızın doğurgan ve üretken kadınları toplumda daha değerli kılmasıyla açıklanabilir. Toplumun bu değer yaklaşımı da kadının kendine olan güvenini arttırarak benlik saygısını olumlu etkiler.

\section{Sonuç:}

Sonuç olarak, sezaryen sonrası annelerin vücut algısı ölçeği puanları ile Rosenberg Benlik Saygısı Ölçeği puanları arasında negatif yönde anlamlı ilişki olduğu, vücut algısı ölçeği puanları arttıkça Rosenberg Benlik Saygısı Ölçeği puanlarının azaldığı görüldü. Çocuk sayısının vücut algısını etkilemediği; ancak benlik saygısını olumlu yönde etkilediği, aylık kazanç ile vücut algısı arasında da anlamlı ilişki olmadığı belirlendi. $\mathrm{Bu}$ sonuçlar doğrultusunda annelerin doğum sonrası döneme uyum sağlaması için oluşabilecek değişimler konusunda bilgi verilmesi, sezaryen sonrası olumlu vücut algisı geliştirmek için girişimlerde bulunulması ve olumlu benlik saygısı geliştirmek için destek sistemlerinin harekete geçirilmesi önerilebilir.

\section{Referanslar:}

1.Sanaati, F, Charandabi, S.M, Eslamlo, H.F, Mirghafourvand, M, A randomized controlled trial on the effect of lifestyle education for Iranian women and their husbands on post-partum anxiety and depression, Health Educ Res. 2018, 33(5), 416-428. doi: 10.1093/her/cyy026.

2. Akildiz, M, Aksoy, Y, Kaydu, A, Kaçar, C.K, Şahin, Ö.F, Yıldırım, Z.B, Elektif Sezaryen Ameliyatlarında Anestezi Yönteminin Preoperatif Anksiyete Düzeylerine Etkisi, Turkish Journal of Anesthesia \& Reanimation, 2017, 45(1), 36-40.

3. Kumcağı, H, Gebe kadınlarda beden algısı ve benlik saygısının bazı değişkenlere göre incelenmes, İnternational Journal of Human Sciences, 2012, 9(2), 691-703.

4. Cırak, R, Özdemir, F, Adölesan Gebelerde Beden İmajı Algısının Belirlenmesi, Anadolu Hemşirelik ve Sağlık Bilimleri Dergisi , 2015, 18(3), 214-221.

5. Roux, S.L, An exploratory study of mothers perceptions and experiences of an unplanned Caesarean section, 2010, 102 (Doctoral dissertation, North-West University).

6.Koyun, A, Taşkın, L, Terzioğlu, F, Yaşam dönemlerine göre kadın sağlığı ve ruhsal işlevler: Hemşirelik yaklaşımlarının değerlendirilmesi, Psikiyatride Güncel Yaklașımlar, 2011, 3(1), 67 99.

7.Van Reenen, S.L, Van Rensburg, E, The influence of an unplanned caesarean section on initial mother-infant bonding: Mothers subjective experiences, Journal of Psychology in Africa, 2013, 23(2), 269-274. 
8. Oguta, T.J, Psychosocial Determinants of Elective Cesarean Section Deliveries in Selected Obstetric Facilities in Nairobi, Kenya Walden Dissertations and Doctoral Studies, 2015, 75-121.

9. İnanir, S, Cakmak, B, Nacar, M.C, Güler, A.E, İnanir, A, Body Image Perception and Self-esteem During Pregnancy, International Journa of Women's Health and Reproduction Sciences, 2015, 3(4), 196-200.

10. Ellis, A, Harper, R.A, La thérapie émotivo-rationnelle [Rational emotive therapy], (3rd ed.). Genève: Ambre éditions, 2007.

11. Farrow, C, Blissett, J, The development of maternal self-esteem, Infant Mental Health Journal, 2007, 8(5), 517-535.

12. Karademir, T, Türkçapar, Ü, Ulucan, H, Bahadır, Z, Haltercilerde benlik saygısı ile yaşam doyum ve vücut benlik algısı arasındaki ilişkinin incelenmesi, Ahi Evran Üniversitesi Kırşehir Eğitim Fakültesi Dergisi, 2013, 14(3), 285-294.

13. Okumuşoğlu, S, Diyet yapan kadınlarda beden algısı, benlik saygısı, yaş ve vücut kitle indeksi ilişkisinin araştırılması, Ulakbilge, 2017, 5(13), 1171-1181.

14. Haspolat, N.K, Kağan, M, Sosyal fobinin yordayıcıları olarak beden imajı ve benlik saygısı, Erzincan Üniversitesi Eğitim Fakültesi Dergisi, 2017, 19(2), 139-152.

15. Çuhadaroğlu, F, Adolesanlarda benlik saygısı, Uzmanlık tezi 1986, Ankara.

16. Oktan, V, Şahin, M, K1z ergenlerde beden imajı ile benlik saygıs arasındaki ilişkinin incelenmesi, Uluslararası İnsan Bilimleri Dergisi, 2010, 7(2), 543-556.

17. Hamurcu, P, Öner, C, Teletar, B, Yeșildağ, Ş, Obezitenin benlik saygısı ve beden algısı üzerine etkisi, Türk Aile Hekimliği Dergisi, $2015,19(3), 122-128$.

18. Yılmaz, N, Obez bireylerde benlik saygısı, sosyal görünüş kaygısı ve vücut algısı, Dokuz Eylül Üniversitesi Tıp Fakültesi Aile Hekimliği Anabilim Dalı Uzmanlık Tezi, 2015, İzmir.

19. Canpolat, B.I, Örsel, S, Akdemir, A, Özbay, M.H, Ergenlerin kendilik algısında beden imajının ve beden kitle indeksinin rolü, Psikiyatri Psikoloji Psikofarmakoloji (3P) Dergisi, 2003, 11(2), 143154.

20. Pop, C, Self-Esteem and Body Image Perception in a Sample of University Students, Eurasian Journal of Educational Research 2016, 64, 31-44.

21. Holzer, L.A, Sevelda, F, Fraberger, G, Bluder, O, Kickinger, W, Holzer, G, Body image and self-esteem in lower-limb amputees, PLoS One, 2014, 9(3), e92943.

22. O'Reilly, A, Choby, D, Séjourné, N, Callahan, S, Feelings of control, unconditional self-acceptance and maternal self-esteem in women who had delivered by caesarean, Journal of Reproductive and Infant Psychology, 2014, 32(4), 355-365.

23. Bacac1, H, Ejder Apay, S, Gebelerde Beden İmajı Alg1sı ve Distres Arasındaki İlişki, Düzce Üniversitesi Sağlık Bilimleri Enstitüsü Dergisi / DÜ Sağlık Bil Enst Derg Journal of Duzce University Health Sciences Institute / J DU Health Sci Inst , ISSN: 2146-443X sbedergi@duzce.edu.tr, 2018,8(2),76-82.

24. Field, S, Onah, M, van Heyningen, T, Honikman, S, Domestic and intimate partner violence among pregnant women in a low resource setting in South Africa: a facility-based, mixed methods study, BMC Womens Health, 2018, 18(1), 119. doi: 10.1186/s12905-018-0612-2.

25. Taşpınar, A, Gebelikte benlik saygısı ve beden imajı ile ilişkili özellikler, Haliç Üniversitesi Psikoloji Anabilim Dalı, 2015, İstanbul.

http://edergi.cbu.edu.tr/ojs/index.php/cbusbed isimli yazarın CBU-SBED başlıklı eseri bu Creative Commons Alınt1-Gayriticari4.0 Uluslararası Lisansı ile lisanslanmıştır. 